\title{
EKSISTENSI ADR DALAM PENYELESAIAN SENGKETA HARTA WARIS PADA MASYARAKAT SUKU SAMAWA
}

\author{
THE EXISTENCE OF ALTERNATIVE DISPUTE RESOLUTION \\ IN SAMAWA TRIBE INHERITANCE DISPUTE
}

\author{
Syarif Dahlan ${ }^{1}$ \\ ${ }^{1}$ Dosen Program Studi Ilmu Hukum Fakultas Hukum Universitas Samawa \\ email : syarif_dahlan66@yahoo.com \\ Iwan Haryanto ${ }^{2}$ \\ ${ }^{2}$ Dosen Program Studi Ilmu Hukum Fakultas Hukum Universitas Samawa \\ Email : iwanhariantosh@gmail.com \\ Naskah diterima : 21/07/2018; direvisi : 12/08/2018; disetujui : 14/08/2018
}

\begin{abstract}
Reduced the number of inheritance dispute settlement through the courts proposed by the samawa people, causing some questions concerning inheritance dispute settlement through alternative dispute resolution (adrs). What are inheritance cases that can be resolved using adrs? form and working mechanism dispute resolution an alternative ( adrs ) ofinheritance dispute settlement? And the effectiveness of an alternative dispute resolution (adrs) of inheritance dispute settlement?.To assess the problems research used in research this law empirical research using qualitative approach. Results from the analysis was found that the inheritance dispute that can be resolved through the alterative dispute resolution (adrs) is the inheritance disputeof immovable goods in this terms is land, then the forms and the heritance dispute resolution mechanism using mediation in which the role of head village as mediator to solve the dispute is very effective.
\end{abstract}

Keywords : Alternative Dispute Resolution (ADR), Dispute, heritance

\begin{abstract}
Abstrak
Berkurangnya angka penyelesaian sengketa harta waris melalui pengadilan yang diajukan oleh masyarakat Suku Samawa, menimbulkan beberapa pertanyaan menyangkut penyelesaian sengketa harta waris melalui mekanisme alternative dispute resolution (ADR). Apa saja kasus sengketa harta waris yang dapat diselesaikan menggunakan ADR? bentuk dan mekanisme kerja alternative dispute resolution (ADR) dalam penyelesaian sengketa harta waris? Dan efektifitas alternative dispute resolution (ADR) dalam penyelesaian sengketa harta waris?. Untuk mengkaji permasalahan tersebut penelitian yang digunakan dalam penelitian ini yakni penelitian hukum empiris dengan menggunakan pedekatan kualitatif. Hasil yang diperoleh dari analisis tersebut ditemukan bahwa sengketa harta waris yang dapat diselesaikan melalui jalur alternative dispute resolution (ADR) yakni sengketa harta waris berupa barang tidak bergerak yakni tanah waris, kemudian bentuk dan mekanisme penyelesaian sengketa harta waris menggunakan jalur mediasi, dimana peran kepala desa sebagai pihak penengah dalam penyelesaian masalah tersebut sehingga efektifitas penyelesaian menggunakan alternative dispute resolution (ADR) sangat efektif.
\end{abstract}

Kata kunci: Alternative Dispute Resolution (ADR), Sengketa, Harta Waris 


\section{PENDAHULUAN}

Kabupaten Sumbawa salah satu daerah yang berada di Nusa Tenggara Barat (NTB) dengan jumlah penduduk sekitar 415.000 jiwa yang tersebar di 24 kecamatan, mulai dari Kecamatan Tarano, Empang, Plampang, Labangka, Maronge, Lape, Lopok, Ropang, Lunyuk, Lenangguar, Orong Telu, Batu Lanteh, Moyo Hulu, Moyo Hilir, Moyo Utara, Lantung, Unter Iwes, Sumbawa, Labuhan Badas, Utan, Buer, Rhee, Alas, Alas Barat.

Masyarakat Kabupaten Sumbawa hidup dalam komunitas Suku Samawa. Suku Samawa merupakan suku yang sudah lama menetap di Kabupaten Sumbawa. Suku ini memiliki tradisi yang hidup dan berkembang di dalam masyarakat, berupa saling tulung, saling tulang dansaling totang sehingga tradisi ini dideskripsikan dalam bentuk selogan Kabupaten Sumbawa yang berbunyi Sabalong Sama Lewa. Makna yang terkandung di dalam selogan tersebut bahwa masyarakat Suku Samawa dalam kehidupan sehari-harinya harus membangun hubungan secara harmonis antar sesama masyarakat, baik masyarakat pendatang maupun masyarakat Suku Samawa itu sendiri melalui hubungan saling tulung (saling membantu antar warga masyarakat atau hubungan saling tolong menolong antara dua orang atau lebih), saling tulang (tegur sapa guna membangun keakraban antar sesama masyarakat), dan saling totang (saling mengingatkan atau saling menasehati kepada kebaikan guna menghindari dari perbuatan keji dan mungkar).

Tradisi Masyarakat Suku Samawa ini merupakan bagian dari penguatan pembagunan pondasi melalui hubungan sosial dengan sesama masyarakat agar terhindar dari perbuatan-perbuatan yang bertentangan dengan nilai-nilai yang hidup di tengah masyarakat Suku Samawa. Tidak hanya itu, tradisi ini merupakan penguatan pondasi moral yang bersifat spiritual agar mendapat kebaikan di dunia maupun di akhirat.

Namun dalam menghadapi dunia kekinian, masyarakat Suku Samawa mulai dihadapi dengan berbagai persoalan. Persoalan ini dapat menciptakan ketidakseimbangan dalam kehidupan masyarakat Suku Samawa, salah satunya adalah masalah harta waris. Harta waris merupakan harta, baik harta bergerak maupun harta tidak bergerak yang ditinggalkan oleh ahli waris untuk dibagi kepala pewaris. Pewaris merupakan subyek hukum yang memiliki hubungan secara langsung dan secara tidak langsung dengan ahli waris. Secara langsung, dikarenakan hubungan darah, perkawinan, sedang secara tidak langsung yaitu melalui wasiat dan hibah.

Pembagian harta waris pada umunya dapat menciptakan keharmonisan dan keseimbangan dalam kehidupan keluarga dan masyarakat agar terhindar dari konflik yang kemungkinan akan terjadi. Di dalam hukum Islam ada beberapa manfaat yang dirasakan oleh pewaris ketika adanya pembagian harta waris, yakni menciptakan ketentraman hidup orang-orang yang melaksanakannya dan membangun nilainilai keadilan yang paling tinggi. Jika keadilan ini akan diterapkan maka secara otomatis akan mencegah muncul berbagai konflik dalam keluarga atau masyarakat. (Maryati Bahtiar, 2014).

Akan tetapi pembagian harta waris yang terjadi pada masyarakat Suku Samawa selalu memunculkan konflik atau sengketa, baik ditingkat keluarga yang lebih dekat (saudara), maupun keluarga yang lebih jauh. Kejadian ini selalu terjadi di masyarakat Suku Samawa yang ada di berbagai kecamatan di Kabupaten Sumbawa. Salah satunya, di Kecamatan Empang. Berdasarkan data Pengadilan Agama Sumbawa pada tahun 2011 ada 11 perkara waris yang diajukan oleh masyarakat. Empat perkara waris berasal dari masyarakat Suku Samawa Kecamatan 
Empang. Tahun 2013, sebanyak 13 perkara waris yang diajukan juga. Lima diantara perkara tersebut berasal masyarakat Suku Samawa Kecamatan Empang. Ratarata perkara tersebut sebagian sudah diselesaikan dan ada juga yang belum diselesaikan guna mendapat keputusan tetap. Dalam perkembangan perkara waris yang diajukan oleh masyarakat Suku Samawa ke Pengadilan Agama Sumbawa. Tahun 2014 ada 7 perkara waris yang diajukan oleh masyarakat Suku Samawa se-Kabupaten Sumbawa. Enam dari jumlah tersebut, hanya 1 saja perkara waris yang berasal dari Kecamatan Empang. Begitu juga dengan tahun 2015, ada 5 perkara waris yang diajukan oleh masyarakat, namun yang berasal dari masyarakat Suku Samawa Kecamatan Empang tidak ada. Perkara waris yang diajukan oleh masyarakat ke Pengadilan Agama Sumbawa, terutama yang berasal dari masyarakat Suku Samawa Kecamatan Empang mulai mengalami penurunan, dan bahkan ada juga perkara waris yang sudah diajukan oleh yang bersangkutan yang berasal dari masyarakat Suku Samawa Kecamatan Empang, namun yang bersangkutan tidak meneruskan lagi untuk menyelesaikannya.

Ini mengindikasikan adanya upaya penyelesaian yang dilakukan oleh para pihak melalui jalur non litigasi (di luar pengadilan) menggunakan alternative dispute resolution (ADR) atau aternatif penyelesaian sengketa. Hal ini didukung oleh beberapa kasus yang diajukan oleh masyarakat ke Kasi Ketentraman dan Ketertiban Kecamatan Empang. Salah satunya kasus sengketa harta waris, di mana Haji Salim melawan saudaranya Haji Abdul Rasyid, Ahmad Yani, Hasanuddin, dan M. Ali pada tahun 2014. Pada tahun 2015, juga terjadi hal yang sama yaitu sengketa harta waris antara Haja Dawi melawan Sabaria dan Fukaya. Kejadian ini tentu memperlihatkan adanya upaya penyelesaian yang digunakan oleh para pihak dalam menyelesaian sengketa harta waris melalui jalur alternative dispute resolution (ADR), baik dalam bentuk menggunakan jalur mediasi, negosiasi, konsultasi, fasilitasi, dan lainlain. Kebolehan penyelesaian perkara diluar pengadilan diatur berdasarkan pasal 1851 , 1855, 1858 KUHPdt, Penjelasan Pasal 3 UU No. 14 Tahun 1970 serta UU No. 30 Tahun 1999 tentang Arbitrase dan Alternatif Penyelesaian Sengketa, maka terbuka kemungkinan para pihak menyelesaikan sengketa dengan menggunakan lembaga selain pengadilan (non litigasi), seperti arbitrase dan musyawarah mufakat atau perdamaian (islah).

Penyelesaian menggunakan alternative dispute resolution (ADR) atau aternatif penyelesaian sengketa merupakan penyelesaian yang secara tidak langsung sudah lama ada dalam kehidupan masyarakat Suku Samawa yang tertanam rapi dan dibudayakan dalam kehidupan masyarakat Suku Samawa. Penyelesaian sengketa menggunakan alternative dispute resolution (ADR) atau alternatif penyelesaian sengketa sangat mudah dipahami, sederhana dan cepat dalam menyelesaikan sengketa, terutama sekali sengketa harta waris yang terjadi di masyarakat Suku Samawa Kecamatan Empang.

Dari uraian dan pemaparan latar belakang di atas, maka penulis terdorong dan tertarik untuk membahas penyelesaian harta waris menggunakan jalur non litigasi atau di luar pengadilan dengan menggunakan ADR yang hidup ditengah masyarakakat Suku Samawa melalui judul Eksistensi Alternative Dispute Resolution Dalam Penyelesaian Sengketa Harta Waris Pada Masyarakat Suku Samawa Di Kecamatan Empang Sumbawa. Untuk mengkaji judul tersebut maka akan diuraikan kedalam rumusan masalah yang terdiri dari:

1. Apa saja kasus sengketa harta waris yang dapat diselesaikan menggunakan 
alternativedisputeresolution(ADR)yang terjadi pada masyarakat Suku Samawa?

2. Bagaimanabentuk dan mekanismekerja alternative dispute resolution (ADR) dalam penyelesaian sengketa harta waris yang terjadipada masyarakat $\mathrm{Suku}$ Samawa?

3. Bagaimana efektifitas alternative dispute resolution (ADR) dalam penyelesaian sengketa harta waris yang terjadi pada masyarakat Suku Samawa?

Untuk menghindari timbulnya pembahasan yang terlalu luas, serta untuk memperoleh gambaran yang jelas dari substansi yang dikaji, maka fokus dan ruang lingkup penelitian ini di titik beratkan pada:

1. Sengketa harta waris yang dapat diselesaikan menggunakan ADR pada masyarakat Suku Samawa.

2. Bentuk-bentuk dan mekanisme kerja ADR yang digunakan dalam penyelesaian sengketa harta waris pada masyarakat Suku Samawa

3. Efektifitas ADR dalam penyelesaian sengketa harta waris pada masyarakat Suku Samawa

Selain itu, tujuan yang diperoleh dalam penelitian ini yakni untuk mengetahui dan mengidentifikasi sengketa harta waris yang dapat diselesaikan menggunakan ADR, untuk mengidentifikasi dan menganalisis bentuk-bentuk dan mekanisme kerja ADR yang digunakan dalam penyelesaian sengketa harta waris pada masyarakat Suku Samawa, serta untuk mengetahui, mengidentifikasi dan menganalisis efektifitas ADR dalam penyelesaian sengketa harta waris pada masyarakat Suku Samawa

Di dalam melakukan kajian terhadap permasalahan tersebut, tentu menggunakan metode penelitian. Penelitian ini merupakan penelitian hukum empiris. Penelitian hukum empiris atau penelitian hukum dengan aspek empiris merupakan hukum dikonsepkan sebagai suatu gejala empiris yang dapat diamati di dalam kehidupan nyata. Dalam konteks ini hukum tidak semata-mata dikonsepkan sebagai suatu gejala normatif yang otonom, sebagai ius constituendum (law as what ought to be), dan tidak pula semata-mata sebagai ius constitutum (law as what it is in the book), akan tetapi secara empiris sebagai ius operatum (law as what it is in society). Hukum sebagai "law as what it is in society", hukum sebagai gejala sosio empirik dapat dipelajari disatu sisi sebagai suatu independent variable yang menimbulkan efek-efek pada berbagai kehidupan sosial dan disisi lain sebagai suatu dependent variabel yang muncul sebagai akibat berbagai ragam kekuatan dalam proses sosial (studi mengena law in process). Jadi penelitian hukum pada aspek empiris yakni melihat bekerjanya hukum dalam kehidupan masyarakat, baik masyarakat tradisional maupun masyarakat modern.

Penelitian hukum pada aspek empiris ini menggunakan pendekatan kualitatif. Pendekatan kualitatif, dimana suatu proses penelitian yang dilakukan secara sistematis dan intensif untuk memperoleh pengetahuan tentang fenomena sosial dengan menggunakan fenomena sosial itu sendiri. Penelitian kualitatif lebih menekankan pada pemahaman terhadap fenomena sosial ditinjau dari perspektif subyek penelitian. Untuk mengkaji penelitian ini dengan menggunakan pendekatan kualitatif yakni mengkaji fenomena sosial menyangkut dengan eksistensi ADR dalam penyelesaian sengketa harta waris pada masyarakat Suku Samawa di Kecamatan Empang Kabupaten Sumbawa. Pengkajian ini secara inten, mendalam, sistematis dan holistik. Di dalam penelitian kualitatifakan menghasilkan data-data deskriptif berupa kata-kata tertulis atau lisan dari orangorang dan prilaku yang dapat diamati. Sehingga data yang dikumpulkan adalah data yang berupa kata/kalimat maupun gambar (bukan angka-angka). Data-data 
ini bisa berupa naskah wawancara, catatan lapangan, foto, video, dokumen pribadi, memo ataupun dokumen resmi lainnya.

Untuk memperoleh data tersebut maka diajukan pertanyaan-pertanyaan yang menyangkut dengan kasus-kasus harta waris yang dapat diselesaikan menggunakan Alternative dispute resolution (ADR), bentuk dan mekanisme alternative dispute resolution (ADR) dalam menyelesaikan sengketa waris, serta efektifitas alternative dispute resolution (ADR) dalam penyelesaian sengketa harta waris. Pertanyaan seputar hal tersebut, salah satu upaya pendalaman secara sistematis dan komprehensif guna menemukan data yang sebenarnya. Selain itu pengumpulan data-data yang berupa dokumen, naskah yang memiliki hubungan dengan permasalahan tersebut, kemudian data tersebut dianalisis menggunakan data primer dan data sekunder sebagai pendukung dalam penelitian ini.

Di dalam penelitian ini ada beberapa tahapan yang akan dilakukan untuk mengkaji eksistensi ADR dalam penyelesaian sengketa harta waris pada masyarakat Suku Samawa yakni mengidentifikasi masalah, mereview informasi, mengumpulkan data menggunakan observasi, dokumentasi dan wawancara, menganalisis data dan menyajikan hasil dan yang terakhir menginterprestasi temuan dan menarik kesimpulan. Adapun tahapan tersebut dapat digambarkan di bawah ini.

Gambar 1: Tahapan Penelitian

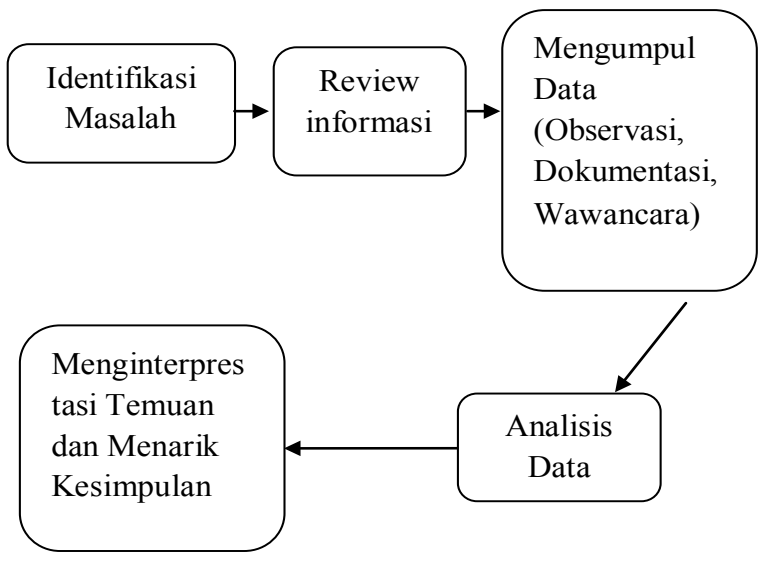

Penelitian berlokasi di wilayah Kecamatan Empang Kabupaten Sumbawa, dengan jarak 100 kilometer dari Kota Sumbawa menuju Kecamatan Empang. Jarak dari kota Kecamatan Empang ke beberapa desa kurang lebih 10 kilometer dan ada yang 30 kilometer. Dalam pengambilan data dilakukan di masyarakat Suku Samawa yang ada di desa. Akan tetapi, tidak menutup kemungkinan dapat dilakukan pengambilan data di tingkat kecamatan (kantor camat) selama pihak kecamatan pernah terlibat dalam penyelesaian sengketa harta waris masyarakat Suku Samawa menggunakan ADR.

Untuk memperoleh data yang jelas dalam penelitian ini, maka jenis data yang diperlukan dalam penelitian ini yakni data lapangan atau data primer dan data kepustakaan atau data sekunder. Data lapangan adalah data yang diperoleh dari penelitian lapangan, di mana data tersebut diperoleh langsung dari sumber pertama di lapangan, dalam hal ini di masyarakat Suku Samawa yang berada dalam wilayah Kecamatan Empang. Data kepustakaan, di mana data tersebut tidak diperoleh secara langsung dari sumber pertamanya, melainkan bersumber dari data yang sudah terdokumenkan dalam bentuk bahanbahan hukum tertulis. Data kepustakaan itu meliputi bahan hukum dan bahan non hukum. Bahan hukum tersebut meliputi bahan hukum primer, hukum sekunder dan bahan hukum tersier, sedangkan bahan non hukum yaitu berupa beritaberita yang termuat dalam media massa maupun media online yang memiliki hubungan dengan masalah yang diangkat dalam penelitian ini.

Data yang diperoleh dalam penelitian ini adalah data lapangan dan data kepustakaan yang berhubungan dengan eksistensi ADR dalam penyelesaian sengketa harta waris. Untuk memperoleh data tersebut, biasanya di dalam penelitian empiris dikenal dengan teknik pengumpulan data yaitu 
teknik pengumpulan data menggunakan studi dokumen, wawancara, observasi, dan penyebaran kuisioner/angket. ${ }^{1}$ Di dalam penelitian ini teknik pengumpulan data yang digunakan:

1. Observasi yaitu pegambilan data dengan cara pengamatan secara sistematis yang teliti dalam hal ini fenomena kasus harta waris dan eksistensi ADR dalam penyelesaian sengketa harta waris yang terjadi pada masyarakat Suku Samawa yang berada di wilayah di Kecamatan Empang.Pengamataninidilakukanpada masyarakat Suku Samawa yang berada di desa-desa.

2. Studi dokumen yaitu pengumpulan data yang bersifat kepustakaan yang berupa naskah, dokumen penting, koran, majalah, media online, peraturan, referensi yang memiliki hubungan dengan penelitian ini.

3. Wawancara mendalam yaitu teknik pengumpulan dengan mengajukan beberapa pertanyaan kepada subyek penelitian guna memperoleh informasi yang lebih mendalam tentang kasus sengketa harta waris dan eksistensi ADR dalam penyelesaian sengketa harta waris yang terjadipada masyarakat $\mathrm{Suku}$ Samawa. Subyek peneliti ini adalah tokoh-tokoh masyarakat Suku Samawa, kepala desa (pemerintah desa), pihak kecamatan(pemerintahkecamatan),dan pihak lain, selama yang bersangkutan pernah terlibat dalam penyelesaian sengketa harta waris menggunakan ADR.

Apabila data sudah terkumpul, baik data primer dan data skunder, maka dilakukan analisis data dengan cara menyusun data secara sistematis, digolongakan dalam pola dan tema, dikategorikan dan diklasifikasikan, dihubungkan antara satu data dengan data lain, kemudian dilakukan interpretasi untuk memahami makna data dalam situasi sosial, dan dilakukan 53

${ }^{1}$ Pendoman Penulisan Usulan Penelitian, op. cit., hlm., penafsiran dari perspektif peneliti setelah memahami keseluruhan kualitas data. Proses analisis tersebut dilakukan secara terus menerus. Setelah dilakukan analisis data tersebut, kemudian data akan disajikan secara deskriptif analitik dan sistematis.

\section{PEMBAHASAN}

\section{Kasus Sengketa Harta Waris Yang Dapat Diselesaikan Menggunakan ADR}

Suku Samawa merupakan suku yang sudah lama menetap di Kabupaten Sumbawa. Suku ini memiliki tradisi yang hidup dan berkembang di dalam masyarakat, berupa saling tulung, saling tulang dan saling totang sehingga tradisi ini dideskripsikan dalam bentuk selogan Kabupaten Sumbawa yang berbunyi Sabalong Sama Lewa. Makna yang terkandung di dalam selogan tersebut bahwa masyarakat Suku Samawa dalam kehidupan sehari-harinya harus membangun hubungan secara harmonis antar sesama masyarakat, baik masyarakat pendatang maupun masyarakat Suku Samawa itu sendiri melalui hubungan saling tulung (saling membantu antar warga masyarakat atau hubungan saling tolong menolong antara dua orang atau lebih), saling tulang (tegur sapa guna membangun keakraban antar sesama masyarakat), dan saling totang (saling mengingatkan atau saling menasehati kepada kebaikan guna menghindari dari perbuatan keji dan mungkar). ${ }^{2}$

Tradisi Masyarakat Suku Samawa ini, bagian dari penguatan pembagunan pondasi melalui hubungan sosial dengan sesama masyarakat agar terhindar dari perbuatan-perbuatan yang bertentangan dengan nilai-nilai yang hidup di tengah masyarakat Suku Samawa. Tidak hanya itu, tradisi ini merupakan penguatan pondasi moral yang bersifat spiritual agar

\footnotetext{
${ }^{2}$ Syaifuddin Iskandar, op. cit, hlm. 74
} 
mendapat kebaikan di dunia maupun di akhirat.

Namun dalam menghadapi dunia kekinian, masyarakat Suku Samawa mulai dihadapi dengan berbagai persoalan. Persoalan ini dapat menciptakan ketidakseimbangan dalam kehidupan masyarakat Suku Samawa sehingga menimbulkan konflik dalam komunitas masyarakat Suku Samawa. Konflik diartikan bagian dari hidup umat manusia dan menjadibagian yang tidak terpisahkan. Sebagaimana dikemukakan oleh Louis Kriesberg, bahwa konflik (sosial) selalu ada di sekitar kita karena mereka inheren dalam hubungan antar manusia. Sementara itu, Coser mengatakan bahwa konflik merupakan pertarungan antara dua atau lebih orang dalam mempertentangkan nilai-nilai, atau dalam kompetisi untuk status, kekuasaan dan sumber daya yang terbatas, di mana tujuan masing-masing pihak adalah menetralisasi, melukai dan menghilangkan lawannya. Secara sosiologis, konflik diartikan sebagai suatu proses sosial antara dua orang atau lebih (bisa juga kelompok) dimana salah satu pihak berusaha menyingkirkan pihak lain dengan menghancurkannya atau membuatnya tidak berdaya. Dalam pendekatan teori konflik, menurut Murdianto bahwa masyarakat dapat dikelompokkan dalam dua kategori yaitu orang yang berkuasa dan mereka yang di kuasai, dualisme inilah yang termasuk struktur dan hakekat tiap-tiap kehidupan bersama mengakibatkan kepentingankepentingan yang berbeda dan mungkin saling berlawanan dan pada akhirnya deferensi kepentingan melahirkan kelompok-kelompok yang berbenturan. ${ }^{3}$ Terjadinya konflik ini tentu disebabkan oleh berbagai hal sebagai pemicu terjadinya konflik. Beberapa sosiolog menjabarkan

\footnotetext{
${ }^{3}$ Amrullah dan Sri Nurhidayat, Analisis Faktor Struktural, Akselerator Dan Trigger (SAT) Konflik 221 Di Kabupaten Sumbawa Tahun 2013, dalam Jurnal Unsa Progress, Volume 21, No1, Februari, Universitas Samawa (UNSA), Sumbawa Besar, 2016, hlm. 13
}

akar penyebab konflik secara lebih luas dan terperinci, yakni disebabkan berbagai hal: ${ }^{4}$

1. Perbedaan antar individu, diantaranya perbedaan pendapat, tujuan, keinginan, pendirian tentang obyek yang dipertentangkan. Dalam realitas sosial tidak ada satupun individu yang memiliki karakter yang sama sehingga perbedaan karakter tersebutlah yang mempengaruhi timbulnya konflik.

2. Benturan antar kepentingan, baik secara ekonomi maupun secara politik, benturan kepentingan ekonomi di picu oleh makin bebasnya berusaha, sehingga banyak diantara kelompok pengusaha saling memperebutkan wilayah pasar dan perluasan wilayah untuk mengembangkan usahanya. Adapun benturan kepentingan politik, yaitu diwarnai oleh dua kelompok yang memiliki kepentingan yang saling berbenturan. Benturan kepentingan tersebut di picu oleh Gejala satu pihak ingin merebut kekuasaan dan kewenangan di dalam masyarakat, dipihak lain terdapat kelompok yang berusaha mempertahankan dan mengembangkan kekuasaan dan kewenangan yang sudah ada ditangan mereka.

3. Perubahan sosial, yang terjadi secara mendadak biasanya menimbulkan kerawanan konflik. Konflik dipicuh oleh keadaan perubahan yang terlalu mendadak biasanya diwarnai oleh gejala di mana tatanan perilaku lama sudah tidak digunakan lagi sebagai pedoman, sedangkan tatanan perilaku yang baru masih simpang siur sehingga banyak kehilangan arah dan pedoman perilaku. Keadaan demikianini, memicu banyak orang bertingkah "semau gue" yang berakibat pada benturan antar kepentingan baik secara invididu

${ }^{4}$ ElLy M. Setiadi dan Usman Kolip, Pengantar Sosiologi Pemahaman Fakta Dan Gejala Permasalahanan Sosiologi; Teori, Aplikasi Dan Pemecahanya. Kencana Prenada Media Group. Jakarta, 2010, hlm. 30 
maupunkelompok. Selainituperubahan yang mendadak akan memunculkan tiga kelompok yang saling bertentangan. Mereka adalah kelompok konservatif yang berusaha sekuat tenaga untuk mempertahankan nilai-nilai lama, kelompok radikal yang menghendaki perubahan secara frontal dan kelompok moderat. Kelompok koservatif identik dengan kelompok orang tua, kelompok radikal identik dengan kelompok muda dan kelompok moderat identik dengan kelompok intelektual muda.

4. Perbedaan kebudayaan, mengakibatkan adanya perasaan in group dan out group yang biasanya diikuti oleh sikap etnosentrisme kelompok, yaitu sikap yang ditunjukkan kepada kelompok lain bahwa kelompoknya adalah paling baik, ideal dan beradab diantara kelompok lain. Jika masing-masing kelompok yang ada dalam kehidupan sosial sama-sama memiliki sifat demikian, maka sikap ini akan memicu timbulnya konflik antar penganut kebudayaan.

Akan tetapi para ahli Sosiologi memandang bahwa empat gejala sosial tersebut di atas bukanlah faktor penyebab utama terjadinya konflik sosial. Empat faktor tersebut adalah faktor pemicu terjadinya konflik, sedangkan pandangan penganut perspektif konsesus, penyebab utama (akar persoalan) dari konflik sosial adalah disfungsi sosial. Artinya nilainilai dan norma-norma sosial yang ada di dalam struktur sosial tidak lagi ditaati, pranata sosial, sistem pengendaliannya tidak berjalan sebagaimana mestinya. Dalam konteks konflik yang terjadi pada masyarakat Suku Samawa yakni disebabkan adanya perubahan sosial dalam kehidupan masyarakat Suku Samawa, mana tatanan perilaku lama sudah tidak digunakan lagi sebagai pedoman, sedangkan tatanan perilaku yang baru masih simpang siur sehingga banyak kehilangan arah dan pedoman perilaku. Akibat perubahan perilaku ini berpengaruh terhadap distribusi sumber daya yang dimiliki oleh masyarakat suku Samawa. Salah satu sumber daya yang dimiliki oleh masyarakat Suku Samawa adalah harta waris.

Harta waris yang dalam istilah fara'id dinamakan tirkah (peninggalan) adalah sesuatu yang ditinggalkan oleh orang yang meninggal, baik berupa uang atau materi lainnya yang dibenarkan oleh syariat Islam untuk diwariskan kepada ahli warisnya. Di dalam Kompilasi Hukum Islam Indonesia, dijelaskan tentang harta warisan atau harta waris Buku II Hukum Kewarisan Bab I Ketentuan Umum Pasal 171 point e, yang dimaksud dengan harta waris adalah harta bawaan ditambah bagian dari harta bersama setelah digunakan untuk keperluan pewaris selama sakit sampai meninggalnya, biaya pengurusan jenazah (tahjiz), pembayaran utang dan pemberian untuk kerabat. ${ }^{5}$ Ini berarti bahwa harta warisan adalah harta baik dalam bentuk benda bergerak maupun benda tidak bergerak yang ditinggalkan oleh pewaris kepada ahli waris setelah di potong biaya lainnya. Di dalam masyarakat Suku Samawa, harta waris diartikan harta yang ditinggalkan oleh ahli waris yang berupa kendaraan, rumah, tanah baik tanah sawah, pekarangan, kebun hingga ladang dengan tanpa ada pemotongan biaya pegurusan jenasah, biaya sakit dan pembayaran utang, karena biaya tersebut sudah ditanggung oleh sanak keluarga yang ditinggalkan.

Harta waris, sebagai faktor pemicu atau faktor penyebab terjadinya konflik pada masyarakat Suku Samawa, tentu adanya keterlibatan para pihak yang berkonflik atau bersengketa. Di dalam hukum perdata yang dimaksud dengan para pihak yang bersengketa adalah sekurangkurangaya terdapat dua pihak yang

${ }^{5}$ Intruksi Presiden RI Nomor 1 tahun 1991 tentang pelaksanaan Kompilasi Hukum Islam Di Indonesia, Direktorat Pembina Peradilan Agama Direktorat Jenderal Bimbingan Masyarakat Islam Dan Penyelengaraan Haji Departemen Agama RI Tahun 2010. 
berseteru yaitu pihak penggugat (eiser, plainitif) atau pihak yang mengajukan gugatan dan pihak tergugat (gedaagde, defendant). Pihak penggugat adalah orang atau badan hukum yang merasa dirugikan oleh pihak tergugat, sehingga mengajukan gugatan atau meminta perlindungan hukum. Sedangkan pihak tergugat, yaitu pihak atau orang atau badan hukum yang mengeluarkan keputusan berdasarkan kewenangan yang diberikan kepadanya sehingga keputusan yang dikeluarkanya di gugat oleh para pihak atau orang maupun badan hukum. ${ }^{6}$ Dalam Antropologi hukum juga dijelaskan mengenai subyek (pihak) yang bersengketa. Hal ini disampaikan oleh Comaroff dan Roberts, yang dikutip dalam tulisan Valerine J.L Kriekhoff mediasi (tinjau dari segi antropologi hukum), adapun di antara pihak yang bersengketa dapat digolongkan sebagai berikut: ${ }^{7}$

a) Individu dengan individu, yang terdiri dari:

- Kelompok yang berbeda, misalnya padasengketabatas tanahyang terjadi antaraindividu dariklenyangberbeda

- Satu kelompok (within group atau inter group), misalnya pada sengketa tanah warisan antara individu satu klen. Bentuk sengketa dinamakan "interhouse" atau "intergenerational"

b) kelompok dengan kelompok (antar kelompok atau intra group) yaitu sengketa antar sub-sub kelompok yang otonom dalam satu kelompok atau antar kelompokyangbesaryangotonom dalam masyarakat. Bentuk ini dinamakan sengketa intrahouse.

Dalam masyarakat modern, individu atau kelompok-kelompok dalam suatu komunitas tidak hanya berinteraksi dengan individu-individu atau kelompok

\footnotetext{
${ }^{6}$ Martitah dan Hery Abduh S, Buku Ajar Hukum Acara PTUN. UGM, Yogyakarta, 2005, hlm. 25

${ }^{7}$ Valerine J.L Kriekhoff, Mediasi (Tinjauan Dari Segi Antropologi Hukum). Dalam Antropologi Hukum: Sebuah Bunga Rampai oleh T.O. Ihromi. Yayasan Obor, Jakarta, 2001. hlm. 225
}

dalam lingkungan komunitasnya sendiri, melainkan juga dapat berinteraksi dengan pihak-pihak dari luar komunitas, baik perorangan, kelompok ataupun lembaga pemerintah maupun swasta. Dengan demikian, benturan-benturan kepentingan antar individu atau kelompok dalam masyarakat mungkin saja terjadi antar individu atau kelompok dalam komunitas. Melainkan bisa juga terjadi sengketa antar individu atau kelompok yang ada dalam suatu komunitas dengan pihak di luar komunitas.

Kaitan dengan pihak yang terlibat dalam konflik atau sengketa harta waris pada masyarakat Suku Samawa yakni orang yang masih memiliki hubungan garis keturunan dengan pewaris, seperti saudara, bapak, ibu dan lain-lain. Hubungan ini dalam hukum Islam disebut dengan ahli waris adalah orang-orang yang karena sebab (keturunan, perkawinan/ perbudakan) berhak mendapatkan bagian dari harta pusaka orang yang meninggal dunia. Di dalam hukum Islam tidak semua yang dikategorikan keluarga adalah otomatis tergolong ahli waris. Dari sisi hubungan kekeluargaan, terdapat dua macam perbedaan status hak waris: ${ }^{8}$

1. Ahli Waris: Keluarga yang saling mewarisi.

2. Ulul Arhaam: Mempunyai hubungan keluarga tapi tidak saling mewarisi langsung; atau dengan kata lain, dia mewarisi jika tidak ada golongan Ahli waris.

Dalam hukum waris Islam bahwa ahli waris terdiri dari 25 (dua puluh lima) golongan, yang terdiri dari 15 (lima belas) golongan dari ahli waris laki-laki antara lain; duda, anak, cucu, ayah, kakek, saudara, keponakan, paman, sepupu dan memerdekakan budak. Sedangkan dari golongan perempuan terdiri dari 10 (sepuluh golongan) antara lain: janda,

\footnotetext{
${ }^{8}$ Anonimi, Pengertian Ahli Waris Dalam Hukum Islam, diakses pada tanggal 31 Juni 2018 melalui websed http://www.jadipintar.com/2013/04/Pengertian-Ahli-Waris-Menurut-Hukum-islam
} 
anak, ibu, ibunya ibu, saudara dan memerdekakan budak. Akan tetapi tidak seluruh ahli waris akan mendapatkan bagian bagian warisan, hanya ahli waris tertentu saja disebabkan karena prinsip keutamaan. ${ }^{9}$

Harta waris merupakan harta, baik harta bergerak maupun harta tidak bergerak yang ditinggalkan oleh ahli waris untuk dibagi kepala pewaris. Keberadaan harta waris ini merupakan harta yang bersifat bergerak dan tidak bergerak yang merupakan obyek sengketa para pihak. Di dalam KUHPerdata barang disebut dengan benda, baik benda bergerak maupun benda tidak bergerak. Hal ini tercantum di dalam Pasal 504 KUH Perdata benda juga dapat dibagi atas benda tidak bergerak dan benda bergerak.

Benda tidak bergerak (onreorende zaken) meliputi:

a. Benda tidak bergerak karena sifatnya sendiri yang menggolongkan ke dalam golongan itu, seperti: tanah serta segala sesuatu yg tetap ada disitu sehingga menjadi kesatuan segala sesuatu yang tetap ada disitu sehingga menjadi kesatuan dengan tanah tersebut. Misalnya bangunan, tanam-tanaman, pohon-pohon, serta kekayaan alam yang ada dalam kandungan bumi dan barangbarang lain yang belum terpisah dari tanah itu.

b. Benda tidak bergerak karena tujuannya menggolongkannya ke dalam golongan ini, yaitu segala barang yang senantiasa digunakan oleh yang mempunyai dan yang menjadi alat tetap pada suatubenda yang tidak bergerak. Misalnya mesin penggilingan padi yg ditempatkan di dalam gedung perusahaan penggilingan beras dan alat-alat percetakan yang ditempatkan dalam gedung percetakan.

\footnotetext{
${ }^{9}$ Fatahullah, Antara Munasakhah Dan Ahli Waris Pengganti Pada Putusan Nomor 0311/Pdt.G/2009/PA. SEL. Jurnal IUS Kajian Hukum dan Keadilan, Vol. 6, No. 1, http://jurnalius.ac.id/ojs/index.php/jurnalIUS/issue/view/39, 2018, hlm. 113 DOI: http://dx.doi.org/10.29303/ius. v6i1.526
}

c. Benda tidak bergerak karena Undangundang menggolongkannya ke dalam golongan itu, yaitu segala hak atas benda yg tidak bergerak, misalnya Hak Bina Usaha, hak hipotek dan hak guna bangunan.

Benda bergerak (rorende zaken) meliputi:

a. Benda bergerak karena sifatnya sendiri menggolongkannya ke dalam golongan itu.Yangtermasukbendabergerakkarena sifatnya sendiri menggolongkannya ke dalam golongan itu ialah segala barang yang dapat dipindahkan dari tempat satu ke tempatlain. Misalnya mobil, meja dan buku.Kecualibenda-bendayangsifatnya bergerak telah ditentukan undangundang termasuk golongan benda yang tidak bergerak.

b. Benda bergerak karena undang-undang menggolongkannya ke dalam golongan itu. Yangtermasukdalamgolonganbenda yang bergerak karena undang-undang menggolongkannya ke dalam golongan itu ialah segala hak atas benda yang bergerak. Misalnya hak piutan, dan hak gadai.

Benda bergerak dapat dibedakan menjadi :

1. Benda bergerak karena sifatnya, yaitu benda yang dapat dipindahkan.

2. Benda bergerak karena ketentuan undang-undang, yaitu hak atas benda bergerak misalnya saham PT.

3. Barang yang dapat dipakai habis dan barang-barang yang dipakai tidak habis

4. Barang-barang yang sudah ada dan yang masih ada.

Berdasarkan hasil penelitian, bahwa sengketa harta waris yang terjadi dalam kehidupan Masyarakat Suku Samawa adalah sengketa barang atau benda tidak bergerak yang berupa tanah yang ditingakalkan oleh pewaris kepada ahli waris. Tanah yang ditingalkan oleh ahli waris yakni berupa tanah pekarangan rumah, tanah sawah dan tanah ladang. 


\section{Bentuk Dan Mekanisme Kerja ADR Dalam Penyelesaian Sengketa Harta Waris.}

Masalah harta warisan bagi sebagian orang dianggap menjadi hal yang sensitif. Tidak jarang permasalahan harta warisan yang berdampak pada perselisihan antar ahli waris yang notabene masih memiliki hubungan keluarga dan bahkan hubungan darah. Tidak sedikit juga masalah sengketa waris ini yang berujung ke pengadilan. Secara normatif, gugatan pembagian harta warisan dapat diajukan ke Pengadilan Negeri di tempat tanah warisan berada. Atau jika perkawinan pewaris dicatatkan di Kantor Urusan Agama, maka dapat mengajukan gugatan ke Pengadilan Agama di tempat tanah warisan tersebut berada. Hal ini diatur di dalam Pasal 188 Kompilasi Hukum Islam (KHI) yang berbunyi, "Para ahli waris baik secara bersama-sama atau perseorangan dapat mengajukan permintaan kepada ahli waris yang lain untuk melakukan pembagian harta warisan. Bila ada diantara ahli waris yang tidak menyetujui permintaan itu, maka yang bersangkutan dapat mengajukan gugatan melalui Pengadilan Agama untuk dilakukan pembagian warisan."

Selanjutnya, mengenai syarat dan prosedur Gugatan Waris sebagai berikut:

1. Gugatan waris diajukan ke Pengadilan Agama oleh penggugat selaku ahli waris dan dapat pula menggunakan jasa pengacara/advokat.

2. Pengajuangugatan waris disertai dengan bukti kematian pewaris dari Lurah/ Kepala Desa dan silsilah ahli warisnya dan dipersiapkan pula dokumen buktibuktikepemilikanobjek sengketa seperti sertifikat, akta jual beli, dan bukti kepemilikan lainnya.

3. Dalam surat gugatan harus memuat secara lengkap objek-objek sengketa mengenai ukuran dan batas-batasnya tanah, merek dan tahun pembuatan dan kalau perlu dengan warnanya jika objeknya berupa mobil/Sepeda motor atau barang-barang elektronik.

4. Pengajuan gugatan waris diajukan ke Pengadilan Agama yang daerah hukumnya meliputi letak barang tetap (objek sengketa) itu berada. Jika barangbarang sengketa itu menyebar kepada beberapa wilayah Pengadilan Agama, maka penggugat dapat memilih salah satunyaPengadilan Agama dimanaobjek sengketa waris itu berada.

5. Setelah gugatan didaftarkan di PengadilanAgama,penggugat/kuasanya tinggal menunggu panggilan sidang yang disampaikan oleh juru sita. Panggilan disampaikan minimal 3 hari kerja sebelum sidang dilaksanakan.

6. Proses sidang dimulai dari upaya perdamaian dan dilanjutkan dengan mediasi jika para pihak hadir di persidangan. Dalam mediasi, para pihak bebas memilih mediator apakah berasal dari hakim atau pihak lain yang sudah memiliki sertifikat mediasi, dan segala biaya pengeluaran mediasi ditanggung oleh penggugat atau kedua belah pihak jika terdapat kesepakatan dengan tergugat. Namun apabila menggunakan hakim mediator tidak dipungut biaya.

7. Setelah proses mediasi dilaksanakan, dan ternyata damai, maka dibuatkan akte perdamaian yang dikuatkan dalam putusan majelis hakim yang bersangkutan. Namun jika tidak terjadi damai,pemeriksaangugatandilanjutkan dengan pembacaan gugatan, jawaban tergugat, replik penggugat, duplik tergugat, pembuktian yang dilanjutkan dengan pemeriksaan setempat, kesimpulan, musyawarah majelis dan putusan.

Walaupun mekanisme tersebut merupakan aturan atau prosedur dalam penyelesaian sengketa harta waris yang dilakukan oleh pihak penggugat dan tergugat melalui pengadilan. Di dalam Antropologi Hukum di kenal penyelesaian sengketa yang terjadi dalam masyarakat 
modern maupun masyarakat tradisional. Hal ini disampaikan oleh Nader dan Todd, bahwa cara mengakhiri sengketa, ada tujuh cara yakni: ${ }^{10}$

a. Membiarkan saja atau lumping it. Pihak yang merasakan diperlakukan yang tidak adil, gagal dalam upaya untuk menekankan tuntutannya dia mengambil keputusan untuk mengabaikan saja masalah atau isu yang menimbulkan tuntutanya dan dia meneruskan hubungan-hubungan dengan pihak yang dirasakan merugikannya. Ini dilakukan karena berbagai kemungkinan seperti kurangnya faktor informasi mengenai bagaimana proses mengajukan keluhan itu ke pengadilan, kurangnya akses ke lembaga pengadilan atau sengaja tidak diproses ke pengadilan karena diperkirakanbahwakerugianlebihbesar dari keuntungannya (dari arti materil maupun kejiwaan).

b. Mengelak (avoidace). Pihak yang merasa dirugikan memilih untuk mengurangi hubungan-hubungan dengan pihak yang merugikanya atau untuk sama sekalimenghentikanhubungantersebut. Misalnya, dalam hubungan bisnis, hal semacam ini bisa terjadi. Dengan mengelak, isu yang menimbulkan keluhan dielakkan saja. Berbeda dengan pemecahan pertama, di mana hubungan-hubunganberlangsung terus, isunya saja di anggap selesai. Dalam hal bentuk kedua ini, pihak yang dirugikan mengelakkannya. Pada bentuk satu hubungan-hubungan tetap diteruskan, padabentukkeduahubungan-hubungan tetap diteruskan, pada bentuk kedua hubungan dapat dihentikan untuk sebagian atau untuk keseluruhan.

c. Paksa atau coercion. Satu pihak memaksakan pemecahan kepada pihak lain. Ini bersifat unilateral.

${ }^{10}$ Iwan Haryanto, Sengketa Usaha Pertambangan Di Wilayah Hutan Elang Dodo Kabupaten Sumbawa, dalam Jurnal Unsa Progress, Volume 21, No. 18, Juni, Universitas Samawa (UNSA), Sumbawa Besar, 2015, hlm. 59
Tindakan yang bersifat memaksakan ini atau ancaman untuk menggunakan kekerasan, pada umumnya mengurangi kemungkinan penyelesaian secara damai.

d. Perundingan (negosiasi). Dua pihak berhadapan merupakan para pengambil keputusan. Pemecahan atas masalah yang dihadapi dilakukan oleh mereka berdua. Mereka sepakat tanpa adanya pihak ketiga yang mencampurinya. Kedua belah pihak berupaya untuk saling meyakinkan. Jadi, mereka membuat aturan mereka sendiri tidak memecahkannya dengan bertitik tolak dari aturan-aturan yang ada.

e. Mediasi (mediation). Pemecahan dilakukan menurut perantara. Cara ini adanya pihak ketiga yang membantu kedua belah pihak yang berselisih pendapat untuk menemukan kesepakatan. Pihak ketiga ini dapat ditentukan oleh kedua belah pihak yang bersengketa atau ditunjukkan oleh yang berwenanguntukitu.Baikmediatoryang merupakan hasil pilihan kedua belah pihak atau karena di tunjuk oleh orang yangmempunyaikekuasaan,keduabelah pihak yang bersengketa harus setuju bahwa jasa-jasa dari seorang mediator akan digunakan dalam upaya mencari pemecahan. Dalam masyarakat kecil (paguyuban), bisa saja tokoh-tokoh yang berperan sebagai mediator juga berperan sebagai arbitrator dan sebagai hakim. Hal yang tidak jauh berbeda di sampaikan oleh Lukasz Rozdeiczer dan Alejandro Alvarez de la Campa, dengan mengatakan "Mediation is a flexible, non-binding dispute resolution process in which a neutral third party (themediator) assists two or more disputants to reach a voluntary, negotiated settlement of their differences. The parties have ultimate control of the decision to settle and the terms of resolution. The mediator uses a variety of skills and techniques to help the parties reachasettlement,buthasnopower tomake 
a decision. The parties remain the decision makers".11

f. Arbitrase. Dua belah pihak yang bersengketa sepakat untuk meminta perantara pihak ketiga, arbitrator, dan sejak semula telah disetujui bahwa mereka akan menerima keputusan dari arbitrator itu.

g. Peradilan (adjudication). Dalam proses ini pihak ketiga mempunyai wewenangan untuk mencampuri pemecahan masalah, lepas dari keinginan para pihak yang bersengketa. Pihak ketiga itu juga berhak membuat keputusan dan menegakkan keputusan itu artinya berupaya bahwa keputusan dilaksanakan.

Bukan hanya itu saja, S Robert juga mengemukakan cara untuk menyelesaikan sengketa di dalam masyarakat adat, yakni dengan cara penggunaan kekerasan, melalui upacara atau ritual misalnya upacara adat, mempermalukan, melalui mahluk-mahluk supranatural, pengucilan, dan melalui pembicaraan (negosiasi maupun menggunakan bantuan pihak ketiga). ${ }^{12}$

Kaitan dengan mekanisme penyelesaian sengketa harta waris yang terjadi pada masyarakat Suku Samawa, akan tetapi mereka lebih menggunakan mekanisme di luar pengadilan. Bentuk dan mekanisme penyelesaian sengketa adalah menggunakan mediasi, dimana para pihak atau masyarakat Suku Samawa mengajukan permasalahanya kepada kepala desa yang berada dalam wilayah masyarakat Suku Samawa, kemudian kedua belah pihak di minta keterangan oleh kepala desa. Dari keterangan kedua belah pihak kepala desa mengkaji secara matang. Setelah itu barulah kepala desa mengambil jalan tengah dengan cara memberikan saran dan masukan kepada kedua belah

\footnotetext{
${ }^{11}$ Lukasz Rozdeiczer dan Alejandro Alvarez De La Campa, Alternative Dispute Resolution Manual:Implementing Commercial Mediation. Samal And Medium Enterprise Departemn The World Bank Group, USA, 2006, hlm. 35

${ }^{12}$ Iwan Haryanto, op. cit, hlm. 60
}

pihak guna mencari titik penyelesaiannya. Jika saran tersebut diterima maka masalah dianggap selesai. Jika selesai, maka dibuat berita acara penyelesaiannya (kesepakatan penyelesaiannya).

\section{Efektifitas ADR Dalam Penyelesaian Sengketa Harta Waris}

Faktor-faktor yang mempengaruhi penegakan hukum atau efektifitas hukum:

a. Faktor hukum itu sendiri (undangundang maupun keputusan)

b. Faktor penegak hukum yakni pihakpihak yang membentuk maupun menerapkan hukum

c. Faktor sarana atau fasilitas yang mendukung penegakan hukum

d. Faktor masyarakat, yakni lingkungan di mana hukum tersebut berlaku atau diterapkan

e. Faktor kebudayaan yakni sebagai hasil karya, cipta dan rasa yang didasarkan pada karsa manusia di dalam pergaulan hidup.

Kaitan dengan tingkat efektifitas penyelesaian sengketa harta waris yang terjadi pada masyarakat Suku Samawa menggunakan alternative dispute resolution (ADR), sangatlah efektif. Hal ini didukung oleh budaya hukum masyarakat yang lebih memilih penyelesaian menggunakan jalur diluar pengadilan sehingga dalam penyelesaiannya sangat mudah, gampang, dan tidak rumit.

Berdasarkan hasil penelitian kasus harta waris yang diajukan oleh masyarakat Suku Samawa melalui mediasi menggunakan peran kepala desa, sebanyak 15 kasus harta waris berupa tanah dalam setahun. Penyelesaian masalah tersebut menggunakan jalur mediasi sebanyak 14 kasus, hanya satu kasus biasanya tidak dapat terselesaikan di tingkat desa atau menggunkan jalur mediasi.

\section{SIMPULAN}

Sengketa harta yang alami oleh Masyarakat Suku Samawa adalah masalah 
harta waris berupa tanah waris, kemudian bentuk dan mekanisme penyelesaian sengketa harta waris menggunakan jalur mediasi dengan tingkat efektifitas penyelesaian menggunakan alternative dispute resolution (ADR) sangat efektif. Mengingat penyelesaian menggunakan jalur diluar pengadilan atau ADR sangat mudah, murah dan gampang maka sangat diharapkan kepada masyarakat dan pemerintah agar dapat melestarikan baik melalui kebiasaan atau melalui penetapan oleh pemerintah daerah guna memperkuat eksistensi penyelesaian sengketa melalui jalur diluar pengadilan.

\section{DAFTAR PUSTAKA}

Anonimi, 2018, Pengertian Ahli Waris Dalam Hukum Islam, diaksek pada tanggal 31 juni 2018 melalui websed http://www.jadipintar. com/2013/04/Pengertian-AhliWaris-Menurut-Hukum-islam

BPS Kabupaten Sumbawa, 2014, Sumbawa Dalam Angka 2014, Katalog BPS: 1102001.5204

Haryanto, Iwan, 2012, "Sengketa Usaha Pertambangan Di Wilayah Hutan Elang Dodo Kabupaten Sumbawa", Tesis Program Pasca Sarjana Universitas Udayana, Denpasar, Bali.

Humas Pengadilan Agama Sumbawa, 2016, "Data Perkara Waris Tahun 2013 dan Tahun 2014 SeKabupaten", disampaikan pada Hari Senin, Tanggal 20 Mei 2016 di kantor Pengadilan Agama Sumbawa.

Kasi Trantib Kecamatan Empang, 2015, "Penangana Kasus Diajukan Oleh Masyarakat Pada Tahun 2014 Dan 2015", Tribun Sumbawa, pada tanggal 10 Februari 2015.

Martitah dan Hery Abduh S, 2005. Buku Ajar Hukum Acara PTUN. UGM,
Yogyakarta

Moleong, Lexy J.,2007, Metodologi Penelitian Kualitatif, Penerbit PT Remaja Rosdakarya Offset, Bandung

Pendoman Penulisan Usulan Penelitian Dan Penulisan Tesis Ilmu Hukum, 2008, Program Studi Magister Ilmu Hukum, Program Pasca Sarjana Universitas Udayana, Denpasar, Bali

Setiadi, ElLy M. dan Usman Kolip, 2010. Pengantar Sosiologi Pemahaman FaktaDan Gejala Permasalahanan Sosiologi; Teori, Aplikasi Dan Pemecahanya. Kencana Prenada Media Group. Jakarta

Subekti, R Dan R. Tjitrosudibio, 2000, Kitap Undang-Undang Hukum Perdata, PT. Pradnya Pratama, Jakarta

Undang-Undang Konpilasi Hukum Islam Indonesia, Edisi Terbaru, 2016 Fokusmedia, Jawa Barat

Valerine J.L Kriekhoff, 2001. Mediasi (Tinjauan Dari Segi Antropologi Hukum). Dalam Antropologi Hukum: Sebuah Bunga Rampai oleh T.O. Ihromi. Yayasan Obor, Jakarta

Widiyana, I Made 2007, Alternative Penyelesaian Sengketa, Cetakan Ke Pertama, Indonesia Business Law Center (IBLC), Jakarta.

Wiyono, Bambang Budi, 2007, Metodelogi Penelitian (Pendekatan Kualitatif, Kuantitatif, Dan Action Research), Depatemen Pendidikan Nasional Universitas Negeri Malang Fakultas Ilmu Pendidikan.

\section{Jurnal:}

Amrullah dan Sri Nurhidayat, 2016, "Analisis Faktor Struktural, Akselerator Dan Trigger (SAT) 
Konflik 221 Di Kabupaten Sumbawa Tahun 2013", dalam Jurnal Unsa Progress, Volume 21, No1, Februari, Universitas Samawa (UNSA), Sumbawa Besar.

Bahtiar, Maryati 2014, "Hukum Waris Islam Dipandang Dari Perspektif Hukum Berkeadilan Gender", dalam Jurnal Ilmu Hukum, Volume 3, No. 1, Fakultas Hukum Universitas Riau

Fatahullah, F., Sugiyarno, S., \& Surayya, I. (2018). ANTARA MUNASAKHAH DAN AHLI WARIS PENGGANTI PADA PUTUSAN NOMOR: 0311/Pdt. G/2009/PA. SEL. Jurnal IUS Kajian Hukum dan Keadilan, 6(1), 110-125. DOI: http://dx.doi. org/10.29303/ius.v6i1.526

Haryanto, Iwan, 2015, "Sengketa Usaha Pertambangan Di Wilayah Hutan Elang Dodo Kabupaten Sumbawa", dalam Jurnal Unsa Progress, Volume 21, No. 18, Juni, Universitas Samawa (UNSA), Sumbawa Besar.

Iskandar, Syaifuddin, 2016, "Kebangkitan Budaya Samawa Sebagai Modal Pembangunan Di Kabupaten Sumbawa", dalam Jurnal Unsa Progress, Volume 21, No. 2, April, Universitas Samawa (UNSA), Sumbawa Besar. 